\title{
Probiotics and prebiotics in clinical tests: an update [version 1;
}

\section{peer review: 2 approved]}

\author{
Harald Brüssow (iD)
}

Laboratory of Gene Technology, Department of Biosystems, KU Leuven University, Kasteelpark Arenberg 21, Leuven, 3001, Belgium

V1 First published: 22 Jul 2019, 8(F1000 Faculty Rev):1157

https://doi.org/10.12688/f1000research.19043.1

Latest published: 22 Jul 2019, 8(F1000 Faculty Rev):1157

https://doi.org/10.12688/f1000research.19043.1

\section{Abstract}

Probiotics have been explored in an exponentially increasing number of clinical trials for their health effects. Drawing conclusions from the published literature for the medical practitioner is difficult since rarely more than two clinical trials were conducted with the same probiotic strain against the same medical condition. Consequently, the European Society for Paediatric Gastroenterology, Hepatology and Nutrition (ESPGHAN) made a few recommendations restricting it to probiotic use against acute gastroenteritis and antibiotic-associated diarrhea. Recent studies also made a strong case for probiotic use against sepsis in preterm and term infants from developing countries. Conclusions on the value of probiotics are best based on detailed meta-analyses (MA) of randomized controlled trials (RCT). Outcomes of MA are discussed in the present review for a number of gastroenterology conditions. Since these MA pool data from trials using different probiotic species, large RCT published sometimes come to different conclusions than MA including these studies. This is not necessarily a contradiction but may only mean that the specific probiotic species did not work under the specified conditions. Positive or negative generalization about probiotics and prebiotics should be avoided. Credible effects are those confirmed in independent trials with a specified probiotic strain or chemically defined prebiotic in a specified patient population under the specified treatment conditions. Even distinct technological preparations of the same probiotic strain might affect clinical outcomes if they alter bacterial surface structures. Underpowered clinical trials are another problem in the probiotic field. Data obtained with sophisticated omics technologies, but derived from less than ten human subjects should be interpreted with caution even when published in high impact journals.

Keywords

probiotic, prebiotic, synbiotic, Lactobacillus, Bifidobacterium, diarrhea, sepsis

\section{Open Peer Review}

Approval Status

1

2

version 1

22 Jul 2019

Faculty Reviews are review articles written by the prestigious Members of Faculty Opinions. The articles are commissioned and peer reviewed before publication to ensure that the final, published version is comprehensive and accessible. The reviewers who approved the final version are listed with their names and affiliations.

1. Gregor Reid ID, University of Western

Ontario, London, Canada

\section{Daniel Merenstein, Georgetown University}

Medical Center, Washington, USA

Any comments on the article can be found at the end of the article. 
Corresponding author: Harald Brüssow (haraldbruessow@yahoo.com)

Author roles: Brüssow H: Conceptualization, Writing - Original Draft Preparation

Competing interests: No competing interests were disclosed.

Grant information: The author(s) declared that no grants were involved in supporting this work.

Copyright: $\odot 2019$ Brüssow H. This is an open access article distributed under the terms of the Creative Commons Attribution License, which permits unrestricted use, distribution, and reproduction in any medium, provided the original work is properly cited.

How to cite this article: Brüssow H. Probiotics and prebiotics in clinical tests: an update [version 1; peer review: 2 approved] F1000Research 2019, 8(F1000 Faculty Rev):1157 https://doi.org/10.12688/f1000research.19043.1

First published: 22 Jul 2019, 8(F1000 Faculty Rev):1157 https://doi.org/10.12688/f1000research.19043.1 


\section{Introduction}

Probiotics are a controversial issue. Whereas, at one extreme, some scientists attribute too many effects for probiotics by claiming that they are responsible for the obesity epidemic, other scientists, at the other extreme, think that probiotics do not contribute more health benefits than eating yoghurt. Although some popular websites handle probiotics as magic bullets, many scientists deplore the contradictory evidence for the health benefits of probiotics. The economic importance of probiotics is high: The global market for probiotics amounted to $\$ 40$ billion in 2017 and is predicted to increase to $\$ 64$ billion by $2023^{1}$.

Part of the controversy over probiotics is due to a lack of precise definitions and the importance of details. Let us start by defining probiotics as "live microorganisms that when administered in adequate amounts confer a health benefit to the host" ${ }^{2}$ and prebiotics as "a substrate that is selectively utilized by host micro-

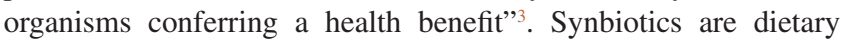
food supplements combining probiotics with prebiotics that support the chosen probiotic. Probiotics have been explored in an exponentially increasing number of clinical trials for their treatment effects ${ }^{4}$ but are also of substantial scientific interest for understanding their mechanism of action and interaction with the microbiome. The vast probiotic literature is not easily summarized in a short review. Care for detail is needed to reach conclusions, making the writing and reading of such a review a difficult task. I will limit this overview to recent randomized clinical trials (RCTs) and meta-analyses (MAs) for a few well-investigated disease states.

Drawing conclusions from the literature in this field is difficult for several reasons. First, the probiotic literature is spread over many different medical conditions (covering health and disease), branches of medicine (from pediatrics to gerontology), and types of countries (from developing to industrialized). Second, the literature covers many different probiotic strains used at different doses and in different formulations such that rarely more than two clinical trials were conducted with the same probiotic strain against the same medical condition. This fact illustrates the difficulty of drawing conclusions from RCTs with probiotics compared with drug trials where a defined chemical compound is tested for its efficacy. This difference also explains why the European Society for Paediatric Gastroenterology, Hepatology and Nutrition (ESPGHAN) made few recommendations on specific probiotics (Lactobacillus rhamnosus GG [LGG] and Saccharomyces boulardii) used against acute gastroenteritis $(\mathrm{AGE})^{5}$ and against antibiotic-associated diarrhea (AAD) while no optimal probiotic strain could be identified for preterm infants despite more than 11,000 subjects enrolled in RCTs $^{6}$. Third, many trials have methodological problems or are underpowered. Conclusions therefore rest largely on MAs. Some MAs come to positive conclusions for the efficacy of probiotics, whereas large individual trials that are part of the MA come up with negative conclusions, indicating that the specific probiotic strain(s) had no effect against the investigated condition. Overstretched negative or positive conclusions from RCTs with probiotics are to be avoided; the conclusion applies only to the specific probiotic tested against the specified clinical conditions.

\section{Diarrhea}

Treatment of acute gastroenteritis

In the most recent Cochrane Review, 63 studies with 8000 mostly pediatric patients ${ }^{7}$ and many different probiotics were evaluated. Despite some variability, the MA showed a statistically significant effect on the primary outcome: duration of diarrhea was reduced by a mean of 24 hours compared with placebo. Since no adverse events were observed, the authors concluded that probiotics could be added to rehydration solutions for the treatment of diarrhea. However, specific probiotic regimens in defined groups of children could not be given. Although the trials included in this MA had methodological limitations (small sample sizes, questionable randomization, and blinding), ESPGHAN still formulated a recommendation ${ }^{5}$.

The following two large trials challenge recommendations for LGG in AGE and raise the issue of strain-specific probiotic effects ${ }^{6,8,9}$ or alteration of LGG by technological processing leading to the loss of pili $^{10}$. A multicenter Canadian RCT randomly assigned children hospitalized with AGE to probiotic treatment with a commercial mixture of L. rhamnosus and Lactobacillus helveticus versus placebo ${ }^{11}$. Duration and severity of diarrhea and vomiting did not differ between the two groups. Stability of the probiotic product was confirmed. However, the L. rhamnosus strain used in the trial differed from the LGG reference strain by displaying different pili genes. A similar multicenter RCT randomly assigned 940 US children to LGG or placebo ${ }^{12}$. Moderate to severe diarrhea developed in $12 \%$ and $13 \%$ of the probiotic and placebo patients, respectively. No significant difference in frequency or duration of diarrhea and vomiting was observed between the two groups. About $40 \%$ of the patients showed no enteropathogen in the stool. Even very-well-performed trials published in high-impact journals, like the two trials, are not beyond criticism. For example, the probiotic treatment started late in the trial ${ }^{11,12}$ such that treatment effects on acute diarrhea could not be expected.

Another MA of six RCTs (representing 1300 children cumulatively) concluded that Bacillus clausii significantly reduced the duration of diarrhea and hospital stay compared with controls ${ }^{13}$, but strain identities were not documented. However, the largest and best controlled of the individual studies showed no effect for a mixture of four B. clausii strains (O/C84, N/R84, T84, and SIN84) $)^{14}$ whereas a recent Indian trial with $B$. clausii UBBC07 spores showed a significant but small reduction in diarrhea duration over placebo (76 versus 82 hours) $)^{15}$.

\section{Prevention of acute gastroenteritis}

There is a paucity of evidence for the prevention of diarrhea by probiotics in the community ${ }^{16}$. In a multicenter clinical trial, more than 400 infants were randomly assigned to a control formula or a test formula containing prebiotic bovine milk oligosaccharides and the probiotic Bifidobacterium lactis; 60 breastfed infants served as a reference group. Diarrhea incidence and incidence of any form of infection measured over the first year of life did not differ significantly between the three groups of children ${ }^{17}$ despite fecal increase of bifidobacteria in infants receiving the test formula ${ }^{18}$. The control group showed a lowerthan-expected diarrhea rate and thus the study was underpowered. 
In diarrhea stools, few enteropathogens were identified, therefore suggesting a high percentage of non-infectious diarrhea in the study. However, an RCT with L. reuteri DSM 17938 in 340 children reported a significant reduction in diarrheal and respiratory infections over a 6-month follow-up period ${ }^{19}$.

\section{Nosocomial diarrhea}

ESPGHAN analyzed data from eight RCTs conducted with different probiotics (LGG, DSM 17938, B. lactis BB-12, $B$. bifidum, two dairy strains) for the prevention of nosocomial diarrhea in 2200 children $^{20}$. Overall, no significant reduction was seen with probiotics over placebo for risk of nosocomial diarrhea, rotavirus diarrhea, or rotavirus shedding. When individual probiotics were evaluated, only Lactobacillus LGG (two RCTs, 800 children) showed a reduction of nosocomial diarrhea from $14 \%$ in controls to $5 \%$ in treated children, but no effect on rotavirus diarrhea was detected (Table 1).

\section{Antibiotic-associated diarrhea}

AAD affects about one third of children treated with antibiotics, which are the most prevalent prescription drugs in pediatrics. An MA of 23 RCTs comprising nearly 4000 patients described a reduction of AAD from $19 \%$ in placebo to $8 \%$ in probiotic-treated patients ${ }^{21}$. The ESPGHAN working group for probiotics/prebiotics recently questioned the practice of pooling different probiotic strains together for $\mathrm{MAs}^{6}$ and suggested that probiotic effects against AAD may be strain-specific ${ }^{22}$ or even depend on the probiotic preparation technique (LGG with or without pili; $\left.{ }^{10}\right)$. Only two probiotics-LGG and $S$. boulardii-were tested in more than one RCT. They both reduced the rate of $\mathrm{AAD}$ to $10 \%$ and $9 \%$ (respectively) compared with 23 to $21 \%$ in corresponding placebo controls. The quality of evidence was moderate. More recently, Lactobacillus plantarum LP299V treatment versus placebo was tested in 440 children receiving antibiotics. No difference was observed between the groups for incidence of AAD or watery stools $^{23}$. Likewise, 250 children treated with antibiotics and randomly assigned to DSM 17938 or placebo did not show a difference in AAD or diarrhea occurrence $^{24}$.

Overdrawn conclusions of small studies. A word of caution is in place with respect to overdrawn conclusions. For example, a recent $\mathrm{Cell}$ article reported that eight human volunteers who received probiotics after antibiotic treatment and gut cleansing showed reduced gut microbiota diversity and delayed return to pre-intervention microbiome composition compared with seven controls ${ }^{25}$. This observation was used on the journal's website to warn against adverse effects of probiotics after antibiotic application. This conclusion ignores data from several studies: of probiotic versus placebo use in nearly 400 mother-child pairs where probiotics corrected undesired microbiota changes caused by antibiotic use or caesarian section ${ }^{26}$; the reduction in IgE-associated allergic diseases in 140 caesariandelivered children treated with probiotics versus controls ${ }^{27}$; and again in a smaller study describing reduced diarrhea in antibiotic-treated Clostridium difficile patients by probiotics ${ }^{28}$, where probiotics did not decrease microbial diversity compared with controls ${ }^{29}$. The probiotics and microbiome areas are not fields to draw conclusions from a single study with few subjects, even though it was conducted by an impressive array of omics-technologies.

\section{Clostridium difficile infection}

C. difficile infection (CDI) causes half a million infections and 30,000 deaths per year in the US. Since antibiotic treatment is a major risk factor for CDI and fecal microbiota transfer is an efficient treatment method, probiotics might be expected to prevent CDI when given as an adjunct to antibiotic treatment. Indeed, a recent MA of 19 studies comprising 6300 patients showed a significant CDI incidence reduction from $3.9 \%$ in the control to $1.6 \%$ in the probiotic group ${ }^{30}$. However, not all studies included in this MA showed efficacy. For example, one large study including 3000 patients found no difference between probiotic (Lactobacillus acidophilus, B. bifidum, B. lactis, $6 \times 10^{10}$ bacteria per day for 21 days given between antibiotic doses) and placebo for any endpoint ${ }^{31}$. Shen et al. ${ }^{30}$ argued that the observed failure might be due to a too-late probiotic application compared with the start of antibiotic treatment and support their conclusion by a regression analysis showing an erosion of the probiotic effect with delayed onset. Allen et al. ${ }^{31}$ observed only a $1 \%$ C. difficile diarrhea (CDD) rate in their study, whereas other studies reported CDD rates of up to $40 \%$. Therefore, patient characteristics might influence trial outcomes, and of course not all strains or strain combinations are going to work, thus reiterating the importance of strain-specific probiotic effects.

\section{Traveler's diarrhea}

Traveler's diarrhea (TD) is a common condition affecting adults traveling to developing countries and is associated with bacterial pathogens like enterotoxigenic Escherichia coli.

Table 1. Effect of different probiotic strains on nosocomial diarrhea.

\begin{tabular}{|l|c|c|c|}
\hline Strain & $\begin{array}{c}\text { Nosocomial } \\
\text { diarrhea }\end{array}$ & $\begin{array}{c}\text { Rotavirus } \\
\text { diarrhea }\end{array}$ & $\begin{array}{c}\text { Rotavirus } \\
\text { shedding }\end{array}$ \\
\hline Lactobacillus rhamnosus GG & + & - & - \\
\hline Lactobacillus reuteri DSM 17938 & - & - & NT \\
\hline Bifidobacterium animalis BB-12 & - & - & NT \\
\hline $\begin{array}{l}\text { Bifidobacterium bifidum, } \\
\text { Streptococcus thermophilus }\end{array}$ & $(+)$ & - & + \\
\hline Lactobacillus delbrueckii H2B20 & - & - & NT \\
\hline
\end{tabular}


The 2017 guidelines of the International Society for Travel Medicine concluded that there is insufficient evidence to recommend prebiotics or probiotics for the prevention or treatment of TD. Older data showed a reduction in TD incidence from $43 \%$ (placebo) to $32 \%$ in Austrian tourists taking a high dose of $S$. boulardii ${ }^{32}$. A recent MA of 11 trials described a small but significant effect of interventions ${ }^{33}$. However, the effect was mediated by prebiotics while probiotics showed no effect $^{33}$. In another study, 330 travelers were randomly assigned to a commercial galacto-oligosacchride (GOS) prebiotic or placebo. Diarrhea incidences were $19 \%$ and $29 \%$, respectively. GOS prevented mild, one-day diarrhea but had no effect on the severity or duration of diarrhea, and the effect became visible only after one week of prebiotic treatment ${ }^{34}$. Like probiotic strains effects, prebiotic effects should be specified according to distinct chemical characteristics of the prebiotics.

\section{Other gastroenterology disorders}

\section{Infant colic}

Let us consider one example in more detail: infant colic or excessive crying without obvious cause. Effects of a gut microbiota disturbance on the immune or intestinal nervous system were hypothesized as possible causes for these occurrences and have motivated probiotic intervention trials. An MA of four RCTs with $L$. reuteri DSM 17938 showed a statistically significant reduction of daily crying time from 160 (placebo) to 140 (probiotic) minutes in breastfed but not in formula-fed infants ${ }^{35,36}$. Since the two groups of infants differed in gut microbiota composition, interaction of $L$. reuteri with the resident microbiota was suspected to influence the probiotic effect ${ }^{37}$.

A recent small trial in breastfed infants confirmed this observation with a greater effect size by halving the crying time ${ }^{38}$. A mixture of eight different probiotics resulted in a reduction of the daily crying time from 98 (placebo) to 68 (probiotic) minutes in another small trial ${ }^{39}$. Also, in a larger trial comparing two lactobacilli plus the prebiotic fructo-oligosaccharide (FOS) against placebo, a significant reduction in crying time was found in breastfed infants ${ }^{40}$. A Cochrane Review ${ }^{41}$ found no evidence that probiotics (L. reuteri, L. rhamnosus, Lactobacillus paracasei, and Bifidobacterium animalis) are more effective than placebo in preventing infantile colic, although crying time was reduced.

\section{Radiation diarrhea}

Gastroenterology problems are the most obvious targets for oral probiotics, and although many conditions have been explored, the evidence level is still mixed $^{42}$. Here, only brief hints to recent literature references are given. An MA on probiotics against radiation therapy-induced diarrhea ${ }^{43}$, which evaluated six RCTs and 900 patients, found a lower incidence of diarrhea in the probiotic versus the placebo group but without observing a sparing effect on frequency and duration of antidiarrhea medication use and stool consistency.

Inflammatory bowel disease. In one MA of probiotic interventions, no benefits of probiotics were found for inducing remission of active Crohn's disease (CD), preventing relapse of quiescent $\mathrm{CD}$, or in surgically induced remission of $\mathrm{CD}^{44}$.
Another MA reported some beneficial effects in reaching remission from ulcerative colitis (UC), but the effects depended on the UC scale adopted and inclusion of bifidobacteria ${ }^{45}$.

Helicobacter pylori. Two MAs on probiotics as adjuncts to antibiotics differed on their conclusion for the eradication of Helicobacter pylori infection, but both analyses reported a reduced incidence of antibiotic-associated adverse side effects ${ }^{46,47}$.

Irritable bowel syndrome. In a trial enrolling 113 celiac disease patients who displayed irritable bowel syndrome (IBS) despite a gluten-free diet, probiotic intervention with a mixture of Lactobacillus casei, L. plantarum, B. animalis, B. lactis, and Bifidobacterium breve improved IBS symptoms over placebo. However, the improvement was not maintained after the cessation of treatment ${ }^{48}$. Fifty-three trials enrolling 5500 patients were evaluated for the effect of different probiotics or probiotic combinations against symptoms in patients with IBS. Although some probiotics showed effects (Lactobacillus on flatulence and Bifidobacterium on abdominal pain), it remained unclear which probiotic combination, species, or strain should be preferred in the individual patient ${ }^{49}$.

\section{Healthy adults}

For regulatory reasons, probiotics are frequently marketed with claims such as boosting immunity or restoring microbiota balances. This raises the question of whether probiotics have an effect in healthy adults, but one should be aware that the definition of health is not precise in the medical literature ${ }^{50}$. An analysis of the literature revealed that interventions with L. plantarum and L. casei or Lactobacillus gasseri, B. longum, and $B$. bifidum as well as with yoghurt starters Lactobacillus delbrueckii and Streptococcus thermophilus reduced the incidence, duration, and symptoms of common cold infections but not of influenza ${ }^{51}$. However, a separate MA showed a stimulation of influenza vaccination by probiotics ${ }^{52}$. Several studies also reported a better gut comfort (improvement in bowel movement, defecation frequency, and stool consistency $)^{51}$. One might add that reduced use of antibiotics against respiratory infections that are likely of viral origin and annual influenza vaccination will undoubtedly have a beneficial effect on the microbiota balance.

\section{Sepsis and necrotizing enterocolitis}

Late-onset sepsis is a major cause of morbidity and mortality in preterm infants from industrialized and developing countries. Rao et $a l^{53}$ conducted an MA of probiotic use against late-onset sepsis in preterm infants including 37 RCT enrolling 9400 infants. The authors described a significant reduction of late-onset sepsis from $16.3 \%$ in placebo to $13.9 \%$ in probiotic recipients. The difference remained significant if analyzed in infants treated with lactobacilli, bifidobacteria, or single or multiple probiotics. A significant reduction of late-onset sepsis and death was also seen in probiotic-treated preterm infants from developing countries ${ }^{54}$.

Necrotizing enterocolitis (NEC) is another severe disease of preterm infants. An MA of 42 RCTs found a significant reduction of NEC and mortality in infants treated with probiotic 
versus placebo ${ }^{55}$. Recent studies investigated species-specific effects and reported prevention of severe NEC with $B$. breve and B. lactis $^{56,57}$, but probiotics had no effect on the relative risk of surgery for $\mathrm{NEC}^{58}$. Multiple-strain probiotics used at high dosage were most effective ${ }^{59}$. Infants treated with a probiotic mix of Bifidobacterium infantis, B. lactis, and S. thermophilus showed a reduction of NEC from $4.4 \%$ (placebo) to $2 \%$ (probiotic) $)^{60}$, whereas infants treated with $B$. breve showed no effect on NEC or death ${ }^{61}$.

The authors of $\mathrm{MAs}^{8,9,53}$ made a strong case for the use of probiotics in preterm infants, arguing that no other interventions showed effects at the low cost of probiotics ( $\$ 1$ per day) $)^{62}$. A small $(2 \%)$ reduction in late-onset sepsis or NEC will make a clinically important difference when neonatal infections are responsible for a quarter of the one million neonatal deaths occurring every year in, for example, India. The authors rejected the argument that different probiotics cannot be pooled in MA. They also argued that some large negative trials were closer to being "inconclusive" than "negative".

A probiotic effect was also seen in an Indian study with 4500 newborns who were randomly assigned to a synbiotic treatment (L. plantarum plus FOS) or placebo. The treatment resulted in a striking $40 \%$ reduction of sepsis, which remained significant for culture-confirmed sepsis ${ }^{63}$. Notably, the study showed a significant reduction of lower respiratory tract infections necessitating antibiotic use and of diarrhea, local infections, and omphalitis. The authors attributed this striking anti-infectious effect to the superior ability of the probiotic to colonize the infant gut. However, the death rate in the infants was not affected.

\section{Future trends}

Each year, about 230 million surgical interventions are performed worldwide; some lead to post-operative complications consisting of surgical site infections, urinary infections, pneumonia, and sepsis. Preventive antibiotic treatment is standard but is complicated by rising antibiotic resistance. A recent network MA of 2952 abdominal surgery patients from 31 studies demonstrated beneficial effects of synbiotics against surgical site infection ${ }^{64}$. Synbiotics (successful trials used mostly L. plantarum, L. casei, and $B$. breve combined with GOS) were also the best interventions to reduce pneumonia, urinary infection, sepsis, hospital stay, and antibiotic use but had no effect on mortality ${ }^{64}$. These authors concluded that surgeons should consider the use of synbiotics as an adjunctive therapy to prevent post-operative complications. Another MA documented the same effects ${ }^{65}$ but concluded that the observations should be interpreted with caution because of a possible publication bias. Two RCTs were recently added to the list of clinical trials. Fifty-five liver transplantation patients received a four-strain probiotic or placebo before the scheduled transplantation. At 90 days after intervention, the infection rate was strikingly lower in probiotic recipients compared with controls (5\% versus $48 \%, P=0.002)^{66}$. In contrast, no synbiotic effect with $L$. paracasei, $L$. rhamnosus, L. acidophilus, and B. lactis plus FOS was seen in
18 head-and-neck cancer patients treated post-operatively compared with 18 placebo-treated controls ${ }^{67}$.

Healthy children receiving human milk oligosaccharides (HMOs) showed a lower rate of bronchitis compared with controls ${ }^{68}$. Several clinical trials with HMOs are registered, and HMOs will likely represent a new trend for prebiotics. Post-bioticschemically defined metabolites or cell wall compounds released by probiotics-could also gain importance in the future ${ }^{69}$. Likewise, probiotics are increasingly explored for application in atopic diseases and skin health as well as vaginal preparations against bacterial vaginosis and associated infection problems ${ }^{70}$. Probiotics might influence the gut-brain axis and thus influence IBS, mood disorders, and anxiety.

\section{Conclusions}

The value of human microbiome-based products is currently estimated to be about $\$ 400$ million worldwide and is expected to reach $\$ 1$ billion over the next five years ${ }^{71}$. Despite the coverage of microbiome research in high-impact scientific journals, the derived products represent a small fraction of the market value of probiotic products. Consumer and industrial interest in probiotics are thus very high, but it should be stressed that probiotics are not magic bullets. Generalizations about "probiotics" should be avoided. If something is linked with medical effects, these are specific strains or specific prebiotic compounds providing a specific health effect in a particular patient group from a particular population. As trivial as this statement is, it is still very difficult to distill these positive conclusions from a complex and sometimes seemingly contradictory research literature. The Human Microbiome Project has already reached entrance into the 2010 edition of Harrison's Principles of Internal Medicine ${ }^{72}$ before the first products of microbiome research appeared at the bedside, while probiotics are found only as small scattered notes in the same standard medical textbook. It is time for the medical curriculum to portray microbes not only as pathogens causing disease but also as important ingredients of human health. Literacy of the next generation of doctors in microbiome and probiotic research is desirable. Microbiologists and clinicians should help in this endeavor by research substantiating specific claims for specific probiotics in specific patients.

\section{Grant information}

The author(s) declared that no grants were involved in supporting this work.

\section{Acknowledgments}

The author thanks Norbert Sprenger (Nestlé Research Center, Lausanne, Switzerland), Jalil Benyacoub (Nestlé Research, Lausanne, Switzerland), and Shawna McCallin (University of Lausanne, Switzerland) for critical reading of the manuscript and reviewers Daniel J. Merenstein (Georgetown University Medical Center, Washington, DC, USA) and Gregor Reid (Lawson Health Research Institute, London, Ontario, Canada) for helpful comments. 
1. Reid G, Gadir AA, Dhir R: Probiotics: Reiterating What They Are and What They Are Not. Front Microbiol. 2019; 10: 424 PubMed Abstract | Publisher Full Text | Free Full Text

2. Hill C, Guarner F, Reid G, et al.: Expert consensus document. The International Scientific Association for Probiotics and Prebiotics consensus statement on the scope and appropriate use of the term probiotic. Nat Rev Gastroenterol Hepatol. 2014; 11(8): 506-14.

PubMed Abstract | Publisher Full Text

3. Gibson GR, Hutkins R, Sanders ME, et al.: Expert consensus document: The International Scientific Association for Probiotics and Prebiotics (ISAPP) consensus statement on the definition and scope of prebiotics. Nat Rev Gastroenterol Hepatol. 2017; 14(8): 491-502. PubMed Abstract | Publisher Full Text

4. McFarland LV: From yaks to yogurt: the history, development, and current use of probiotics. Clin Infect Dis. 2015; 60 Suppl 2: S85-90. PubMed Abstract | Publisher Full Text

5. Szajewska H, Guarino A, Hojsak I, et al.: Use of probiotics for management of acute gastroenteritis: a position paper by the ESPGHAN Working Group for Probiotics and Prebiotics. J Pediatr Gastroenterol Nutr. 2014; 58(4): 531-9. PubMed Abstract | Publisher Full Text

6. F van den Akker CHP, van Goudoever JB, Szajewska H, et al:: Probiotics for Preterm Infants: A Strain-Specific Systematic Review and Network Metaanalysis. J Pediatr Gastroenterol Nutr. 2018; 67(1): 103-22. PubMed Abstract | Publisher Full Text | F1000 Recommendation

7. Allen SJ, Martinez EG, Gregorio GV, et al.: Probiotics for treating acute infectious diarrhoea. Cochrane Database Syst Rev. 2010; (11): CD003048. PubMed Abstract | Publisher Full Text | Free Full Text

8. Athalye-Jape G, Rao S, Patole S: Lactobacillus reuteri DSM 17938 as a Probiotic for Preterm Neonates: A Strain-Specific Systematic Review. JPEN J Parenter Enteral Nutr. 2016; 40(6): 783-94.

PubMed Abstract | Publisher Full Text

9. $\quad \mathrm{F}$ Athalye-Jape G, Rao S, Simmer K, et al:: Bifidobacterium breve M-16V as a Probiotic for Preterm Infants: A Strain-Specific Systematic Review. JPEN J Parenter Enteral Nutr. 2018; 42(4): 677-88.

PubMed Abstract | Publisher Full Text | F1000 Recommendation

10. Kiekens S, Vandenheuvel D, Broeckx G, et al.: Impact of spray-drying on the pil of Lactobacillus rhamnosus GG. Microb Biotechnol. 2019.

PubMed Abstract | Publisher Full Text

11. F Freedman SB, Williamson-Urquhart S, Farion KJ, et al.: Multicenter Trial of a Combination Probiotic for Children with Gastroenteritis. N Engl J Med. 2018; 379(21): 2015-26.

PubMed Abstract | Publisher Full Text | F1000 Recommendation

12. F Schnadower D, Tarr PI, Casper TC, et al.: Lactobacillus rhamnosus GG versus Placebo for Acute Gastroenteritis in Children. N Engl J Med. 2018; 379(21): 2002-14.

PubMed Abstract | Publisher Full Text | Free Full Text | F1000 Recommendation

13. F laniro G, Rizzatti G, Plomer M, et al.: Bacillus clausii for the Treatment of Acute Diarrhea in Children: A Systematic Review and Meta-Analysis of Randomized Controlled Trials. Nutrients. 2018; 10(8): pii: E1074. PubMed Abstract | Publisher Full Text | Free Full Text | F1000 Recommendation

14. Canani RB, Cirillo P, Terrin G, et al:: Probiotics for treatment of acute diarrhoea in children: randomised clinical trial of five different preparations. BMJ. 2007; 335(7615): 340.

PubMed Abstract | Publisher Full Text | Free Full Text

15. F Sudha MR, Jayanthi N, Pandey DC, et al:: Bacillus clausii UBBC-07 reduces severity of diarrhoea in children under 5 years of age: a double blind placebo controlled study. Benef Microbes. 2019; 10(2): 149-54.

PubMed Abstract | Publisher Full Text | F1000 Recommendation

16. Guarino A, Guandalini S, Lo Vecchio A: Probiotics for Prevention and Treatment of Diarrhea. J Clin Gastroenterol. 2015; 49 Suppl 1: S37-S45.

PubMed Abstract | Publisher Full Text

17. Radke M, Picaud JC, Loui A, et al:: Starter formula enriched in prebiotics and probiotics ensures normal growth of infants and promotes gut health: a randomized clinical trial. Pediatr Res. 2017; 81(4): 622-31. PubMed Abstract | Publisher Full Text

18. Simeoni $\mathrm{U}$, Berger B, Junick J, et al.: Gut microbiota analysis reveals a marked shift to bifidobacteria by a starter infant formula containing a synbiotic of bovine milk-derived oligosaccharides and Bifidobacterium animalis subsp. lactis CNCM I-3446. Environ Microbiol. 2016; 18(7): 2185-95.

PubMed Abstract | Publisher Full Text

19. Gutierrez-Castrellon P, Lopez-Velazquez G, Diaz-Garcia L, et al.: Diarrhea in preschool children and Lactobacillus reuteri: a randomized controlled trial. Pediatrics. 2014; 133(4): e904-e909.

PubMed Abstract | Publisher Full Text

20. F Hojsak I, Szajewska H, Canani RB, et al:: Probiotics for the Prevention of Nosocomial Diarrhea in Children. J Pediatr Gastroenterol Nutr. 2018; 66(1): 3-9. PubMed Abstract | Publisher Full Text | F1000 Recommendation

21. Goldenberg JZ, Lytvyn L, Steurich J, et al:: Probiotics for the prevention of pediatric antibiotic-associated diarrhea. Cochrane Database Syst Rev. 2015; (12): CD004827.

PubMed Abstract | Publisher Full Text

22. Szajewska H, Canani RB, Guarino A, et al:: Probiotics for the Prevention of Antibiotic-Associated Diarrhea in Children. J Pediatr Gastroenterol Nutr. 2016; 62(3): 495-506.

PubMed Abstract | Publisher Full Text

23. Olek A, Woynarowski M, Ahrén IL, et al:: Efficacy and Safety of Lactobacillus plantarum DSM 9843 (LP299V) in the Prevention of Antibiotic-Associated Gastrointestinal Symptoms in Children-Randomized, Double-Blind, PlaceboControlled Study. J Pediatr. 2017; 186: 82-6.

PubMed Abstract | Publisher Full Text

24. Kołodziej M, Szajewska H: Lactobacillus reuteri DSM 17938 in the prevention of antibiotic-associated diarrhoea in children: protocol of a randomised controlled trial. BMJ Open. 2017; 7(1): e013928.

PubMed Abstract | Publisher Full Text | Free Full Text

25. F Suez J, Zmora N, Zilberman-Schapira G, et al:: Post-Antibiotic Gut Mucosal Microbiome Reconstitution Is Impaired by Probiotics and Improved by Autologous FMT. Cell. 2018; 174(6): 1406-1423.e16.

PubMed Abstract | Publisher Full Text | F1000 Recommendation

26. Korpela K, Salonen A, Vepsäläinen O, et al:: Probiotic supplementation restores normal microbiota composition and function in antibiotic-treated and in caesarean-born infants. Microbiome. 2018; 6(1): 182. PubMed Abstract | Publisher Full Text | Free Full Text

27. Kuitunen M, Kukkonen K, Juntunen-Backman K, et al.: Probiotics prevent IgEassociated allergy until age 5 years in cesarean-delivered children but not in the total cohort. J Allergy Clin Immunol. 2009; 123(2): 335-41. PubMed Abstract | Publisher Full Text

28. Barker AK, Duster M, Valentine $\mathrm{S}$, et al:: A randomized controlled trial of probiotics for Clostridium difficile infection in adults (PICO). J Antimicrob Chemother. 2017; 72(11): 3177-80.

PubMed Abstract | Publisher Full Text | Free Full Text

29. De Wolfe TJ, Eggers S, Barker AK, et al:: Oral probiotic combination of Lactobacillus and Bifidobacterium alters the gastrointestinal microbiota during antibiotic treatment for Clostridium difficile infection. PLOS One. 2018; 13(9): e0204253.

PubMed Abstract | Publisher Full Text | Free Full Text

30. F Shen NT, Maw A, Tmanova LL, et al.: Timely Use of Probiotics in Hospitalized Adults Prevents Clostridium difficile Infection: A Systematic Review With MetaRegression Analysis. Gastroenterology. 2017; 152(8): 1889-1900.e9. PubMed Abstract | Publisher Full Text | F1000 Recommendation

31. F Allen SJ, Wareham $\mathrm{K}$, Wang $\mathrm{D}$, et al.: Lactobacilli and bifidobacteria in the prevention of antibiotic-associated diarrhoea and Clostridium difficile diarrhoea in older inpatients (PLACIDE): a randomised, double-blind, placebocontrolled, multicentre trial. Lancet. 2013; 382(9900): 1249-57. PubMed Abstract | Publisher Full Text | F1000 Recommendation

32. Kollaritsch $\mathrm{H}$, Holst $\mathrm{H}$, Grobara $\mathrm{P}$, et al.: [Prevention of traveler's diarrhea with Saccharomyces boulardii. Results of a placebo controlled double-blind study]. Fortschr Med. 1993; 111(9): 152-6.

PubMed Abstract

33. F Bae JM: Prophylactic efficacy of probiotics on travelers' diarrhea: an adaptive meta-analysis of randomized controlled trials. Epidemiol Health. 2018; 40: e2018043.

PubMed Abstract | Publisher Full Text | Free Full Text | F1000 Recommendation

34. Hasle G, Raastad R, Bjune G, et al:: Can a galacto-oligosaccharide reduce the risk of traveller's diarrhoea? A placebo-controlled, randomized, double-blind study. J Travel Med. 2017; 24(5): tax057. PubMed Abstract | Publisher Full Text

35. F Sung V, D'Amico F, Cabana MD, et al.: Lactobacillus reuteri to Treat Infant Colic: A Meta-analysis. Pediatrics. 2018; 141(1): pii: e20171811. PubMed Abstract | Publisher Full Text | F1000 Recommendation

36. F Gutiérrez-Castrellón P, Indrio F, Bolio-Galvis A, et al:: Efficacy of Lactobacillus reuteri DSM 17938 for infantile colic: Systematic review with network meta-analysis. Medicine (Baltimore). 2017; 96(51): e9375. PubMed Abstract | Publisher Full Text | Free Full Text | F1000 Recommendation

37. Sung V, Hiscock $\mathrm{H}$, Tang ML, et al.: Treating infant colic with the probiotic Lactobacillus reuteri: double blind, placebo controlled randomised trial. BMJ. 2014; 348: g2107.

PubMed Abstract | Publisher Full Text | Free Full Text

38. F Savino F, Garro M, Montanari P, et al:: Crying Time and RORy/FOXP3 Expression in Lactobacillus reuteri DSM17938-Treated Infants with Colic: A Randomized Trial. J Pediatr. 2018; 192: 171-177.e1. PubMed Abstract | Publisher Full Text | F1000 Recommendation

39. $F$ Baldassarre ME, Di Mauro A, Tafuri S, et al:: Effectiveness and Safety of a Probiotic-Mixture for the Treatment of Infantile Colic: A Double-Blind, Randomized, Placebo-Controlled Clinical Trial with Fecal Real-Time PCR and NMR-Based Metabolomics Analysis. Nutrients. 2018; 10(2): pii: E195. PubMed Abstract | Publisher Full Text | Free Full Text | F1000 Recommendation 
40. F Gerasimov S, Gantzel J, Dementieva N, et al: Role of Lactobacillus rhamnosus (FloraActive ${ }^{\mathrm{TM}}$ ) 19070-2 and Lactobacillus reuteri (FloraActive ${ }^{\mathrm{TM}}$ ) 12246 in Infant Colic: A Randomized Dietary Study. Nutrients. 2018; 10(12): pii: E1975

PubMed Abstract | Publisher Full Text | Free Full Text | F1000 Recommendation

41. F Ong TG, Gordon M, Banks SS, et al.: Probiotics to prevent infantile colic. Cochrane Database Syst Rev. 2019; 3: CD012473.

PubMed Abstract | Publisher Full Text | Free Full Text | F1000 Recommendation

42. Quigley EMM: Prebiotics and Probiotics in Digestive Health. Clin Gastroenterol Hepatol. 2019; 17(2): 333-44.

PubMed Abstract | Publisher Full Text

43. F Liu MM, Li ST, Shu Y, et al.: Probiotics for prevention of radiation-induced diarrhea: A meta-analysis of randomized controlled trials. PLOS One. 2017; 12(6): e0178870.

PubMed Abstract | Publisher Full Text | Free Full Text | F1000 Recommendation

44. F Derwa Y, Gracie DJ, Hamlin PJ, et al.: Systematic review with meta-analysis: the efficacy of probiotics in inflammatory bowel disease. Aliment Pharmacol Ther. 2017; 46(4): 389-400.

PubMed Abstract | Publisher Full Text | F1000 Recommendation

45. F Astó E, Méndez I, Audivert S, et al.: The Efficacy of Probiotics, Prebiotic Inulin-Type Fructans, and Synbiotics in Human Ulcerative Colitis: A Systematic Review and Meta-Analysis. Nutrients. 2019; 11(2): pii: E293. PubMed Abstract | Publisher Full Text | Free Full Text | F1000 Recommendation

46. Lu C, Sang J, $\mathrm{He} \mathrm{H}$, et al:: Probiotic supplementation does not improve eradication rate of Helicobacter pylori infection compared to placebo based on standard therapy: a meta-analysis. Sci Rep. 2016; 6: 23522. PubMed Abstract | Publisher Full Text | Free Full Text

47. Lü M, Yu S, Deng J, et al.: Efficacy of Probiotic Supplementation Therapy for Helicobacter pylori Eradication: A Meta-Analysis of Randomized Controlled Trials. PLoS One. 2016; 11(10): e0163743.

PubMed Abstract | Publisher Full Text | Free Full Text

48. F Francavilla R, Piccolo M, Francavilla A, et al:: Clinical and Microbiological Effect of a Multispecies Probiotic Supplementation in Celiac Patients With Persistent IBS-type Symptoms: A Randomized, Double-Blind, Placebocontrolled, Multicenter Trial. J Clin Gastroenterol. 2019; 53(3): e117-e125. PubMed Abstract | Publisher Full Text | Free Full Text | F1000 Recommendation

49. F Ford AC, Harris LA, Lacy BE, et al:: Systematic review with meta-analysis: the efficacy of prebiotics, probiotics, synbiotics and antibiotics in irritable bowel syndrome. Aliment Pharmacol Ther. 2018; 48(10): 1044-60. PubMed Abstract | Publisher Full Text | F1000 Recommendation

50. Brüssow H: What is health? Microb Biotechnol. 2013; 6(4): 341-8. PubMed Abstract | Publisher Full Text | Free Full Text

51. Khalesi S, Bellissimo N, Vandelanotte $\mathrm{C}$, et al.: A review of probiotic supplementation in healthy adults: helpful or hype? Eur J Clin Nutr. 2019; 73(1): 24-37.

PubMed Abstract | Publisher Full Text

52. F Lei WT, Shih PC, Liu SJ, et al.: Effect of Probiotics and Prebiotics on Immune Response to Influenza Vaccination in Adults: A Systematic Review and Meta-Analysis of Randomized Controlled Trials. Nutrients. 2017; 9(11): pii: E1175.

PubMed Abstract | Publisher Full Text | Free Full Text | F1000 Recommendation

53. Rao SC, Athalye-Jape GK, Deshpande GC, et al:: Probiotic Supplementation and Late-Onset Sepsis in Preterm Infants: A Meta-analysis. Pediatrics. 2016; 137(3): e20153684.

PubMed Abstract | Publisher Full Tex

54. F Deshpande G, Jape G, Rao S, et al:: Benefits of probiotics in preterm neonates in low-income and medium-income countries: a systematic review of randomised controlled trials. BMJ Open. 2017; 7(12): e017638. PubMed Abstract | Publisher Full Text | Free Full Text | F1000 Recommendation

55. F Sawh SC, Deshpande S, Jansen S, et al:: Prevention of necrotizing enterocolitis with probiotics: a systematic review and meta-analysis. PeerJ. 2016; 4: e2429.

PubMed Abstract | Publisher Full Text | Free Full Text | F1000 Recommendation

56. F Hagen PC, Skelley JW: Efficacy of Bifidobacterium Species in Prevention of Necrotizing Enterocolitis in Very-Low Birth Weight Infants. A Systematic Review. J Pediatr Pharmacol Ther. 2019; 24(1): 10-5.

PubMed Abstract | Publisher Full Text | Free Full Text | F1000 Recommendation

57. F Zhu XL, Tang XG, Qu F, et al.: Bifidobacterium may benefit the prevention of necrotizing enterocolitis in preterm infants: A systematic review and metaanalysis. Int J Surg. 2019; 61: 17-25.

PubMed Abstract | Publisher Full Text | F1000 Recommendation

58. F Rees CM, Hall NJ, Fleming P, et al:: Probiotics for the prevention of surgical necrotising enterocolitis: systematic review and meta-analysis. BMJ Paediatr Open. 2017; 1(1): e000066.

PubMed Abstract | Publisher Full Text | Free Full Text | F1000 Recommendation

59. F Sun J, Marwah G, Westgarth M, et al.: Effects of Probiotics on Necrotizing Enterocolitis, Sepsis, Intraventricular Hemorrhage, Mortality, Length of Hospital Stay, and Weight Gain in Very Preterm Infants: A Meta-Analysis. Adv Nutr. 2017; 8(5): 749-63.

PubMed Abstract | Publisher Full Text | Free Full Text | F1000 Recommendation

60. Jacobs SE, Tobin JM, Opie GF, et al:: Probiotic effects on late-onset sepsis in very preterm infants: a randomized controlled trial. Pediatrics. 2013; 132(6): 1055-62.

PubMed Abstract | Publisher Full Text

61. Costeloe K, Hardy P, Juszczak E, et al:: Bifidobacterium breve BBG-001 in very preterm infants: a randomised controlled phase 3 trial. Lancet. 2016; 387(10019): 649-60.

PubMed Abstract | Publisher Full Text

62. Athalye-Jape G, Patole S: Probiotics for preterm infants - time to end all controversies. Microb Biotechnol. 2019; 12(2): 249-53. PubMed Abstract | Publisher Full Text | Free Full Tex

63. F Panigrahi P, Parida S, Nanda NC, et al:: A randomized synbiotic trial to prevent sepsis among infants in rural India. Nature. 2017; 548(7668): 407-12. PubMed Abstract | Publisher Full Text | F1000 Recommendation

64. F Kasatpibal N, Whitney JD, Saokaew S, et al:: Effectiveness of Probiotic, Prebiotic, and Synbiotic Therapies in Reducing Postoperative Complications: A Systematic Review and Network Meta-analysis. Clin Infect Dis. 2017; 64(suppl 2): S153-S160.

PubMed Abstract | Publisher Full Text | F1000 Recommendation

65. F Yang Z, Wu Q, Liu Y, et al.: Effect of Perioperative Probiotics and Synbiotics on Postoperative Infections After Gastrointestinal Surgery: A Systematic Review With Meta-Analysis. JPEN J Parenter Enteral Nutr. 2017; 41(6): 1051-62.

PubMed Abstract | Publisher Full Text | F1000 Recommendation

66. F Grąt M, Wronka KM, Lewandowski Z, et al.: Effects of continuous use of probiotics before liver transplantation: A randomized, double-blind, placebocontrolled trial. Clin Nutr. 2017; 36(6): 1530-9. PubMed Abstract | Publisher Full Text | F1000 Recommendation

67. F Lages PC, Generoso SV, Correia MITD: Postoperative symbiotic in patients with head and neck cancer: a double-blind randomised trial. Br J Nutr. 2018; 119(2): 190-5.

PubMed Abstract | Publisher Full Text | F1000 Recommendation

68. Puccio G, Alliet P, Cajozzo C et al: Effects of Infant Formula With Human Milk Oligosaccharides on Growth and Morbidity: A Randomized Multicenter Trial. J Pediatr Gastroenterol Nutr. 2017; 64(4): 624-31.

PubMed Abstract | Publisher Full Text | Free Full Text

69. Aguilar-Toalá JE, Garcia-Varela R, Garcia HS, et al.: Postbiotics: An evolving term within the functional foods field. Trends Food Sci Technol. 2018; 75: 105-14. Publisher Full Text

70. Martinez RCR, Franceschini SA, Patta MC, et al.: Improved cure of bacterial vaginosis with single dose of tinidazole $(2 \mathrm{~g})$, Lactobacillus rhamnosus GR-1, and Lactobacillus reuteri RC-14: a randomized, double-blind, placebocontrolled trial. Can J Microbiol. 2009; 55(2): 133-8. PubMed Abstract | Publisher Full Text

71. Proctor L: Priorities for the next $\mathbf{1 0}$ years of human microbiome research Nature. 2019; 569(7758): 623-5.

PubMed Abstract | Publisher Full Text

72. Gordon J, Knight R: The human microbiome. In: Longo D L (ed) Harrison's Principles of Internal Medicine, 18th ed. McGraw Hill New York. 2012; 526-535. 


\section{Open Peer Review}

\section{Current Peer Review Status:}

\section{Editorial Note on the Review Process}

Faculty Reviews are review articles written by the prestigious Members of Faculty Opinions. The articles are commissioned and peer reviewed before publication to ensure that the final, published version is comprehensive and accessible. The reviewers who approved the final version are listed with their names and affiliations.

\section{The reviewers who approved this article are:}

\section{Version 1}

\section{Daniel Merenstein}

Georgetown University Medical Center, Washington, DC, USA

Competing Interests: DM has consulted for Bayer \& Pharmavite

\section{Gregor Reid (iD)}

Lawson Health Research Institute, University of Western Ontario, London, ON, N6A 4V2, Canada

Competing Interests: No competing interests were disclosed.

The benefits of publishing with F1000Research:

- Your article is published within days, with no editorial bias

- You can publish traditional articles, null/negative results, case reports, data notes and more

- The peer review process is transparent and collaborative

- Your article is indexed in PubMed after passing peer review

- Dedicated customer support at every stage

For pre-submission enquiries, contact research@f1000.com 